\title{
Climate Change and Implications for Agriculture Sector in Sindh Province of Pakistan
}

\author{
Heman Das Lohano', Fateh Muhammad Mari² \\ RECEIVED ON 19.03.2019, ACCEPTED ON 03.05.2019
}

\begin{abstract}
Pakistan is a highly vulnerable country in the world to climate change. It is ranked among the five most affected countries in the world. Sindh, among the provinces of Pakistan, is located in the southern part and it stands to suffer not only directly from local climatic and weather changes but also from the weather activities in the upstream Indus River and from the coastal environments. This study aims to examine the past trend and future projections of climate variables, assess the climate change impacts on agriculture sector, and recommend adaptation measures for Sindh. The results show that there is statistically significant trend in the temperature and precipitation in some parts of Sindh. The results from climate change projections show that the average annual temperature in Sindh by the end of $21^{\text {st }}$ century may increase by 2 to $5{ }^{\circ} \mathrm{C}$ depending on various emission scenarios. Furthermore, the climate change in Sindh is likely to decrease productivity of agriculture and household income. The study recommends infrastructural development, technological change, institutional reforms, information sharing, and effective regulations to make agriculture sector and other related sectors resilient to climate change.
\end{abstract}

Keywords: Climate change, agriculture, projections, impacts, adaptation, Sindh, Pakistan

\section{INTRODUCTION}

$\mathrm{P}$ akistan is a highly vulnerable country in the world in relation to climate change [1]. Global Climate Risk Index 2020 report has ranked Pakistan on number five among the most affected countries in the world in terms of impacts of extreme weather events during the period 1998-2018, with average annual losses of 3.8 billion USD-PPP ( 0.53 percent of GDP) [2].

Sindh province of Pakistan is located in the intense heat zone, and rise in temperatures due to climate change can further aggravate the conditions. Furthermore, Sindh is located in southern part of the Indus River, and thus stands to suffer not only directly from the local climatic and weather changes but also from the weather activities in the upstream Indus River and from the coastal environments [3]. Floods in Sindh have mostly been associated with precipitation and excess flow of water from the upper part of Indus River. Similarly, effects of shortage of water and droughts in Sindh are aggravated with less precipitation and less flow of water from the upper part of Indus River. Furthermore, coastal areas of Sindh are affected by sea intrusion and rising sea level in Arabian Sea [3].

The vulnerability of agriculture sector is very high to the climatic changes as variation in temperature and precipitation directly affects the agricultural production [4]. Various studies worldwide have been conducted on the impacts of climate change on agriculture, including studies on Pakistan [5-9]. Such impacts are especially significant for Pakistan, where agriculture sector accounts for 19.3 percent of GDP and 38.5 percent of employment as reported in recent Pakistan Economic Survey [10]. Agriculture sector

${ }^{1}$ Department of Economics, Institute of Business Administration, Karachi. Email: hlohano@iba.edu.pk

${ }^{2}$ Higher Education Commission, Islamabad, Pakistan.

Email: fateh.marri@hec.gov.pk (Corresponding Author)

This is an open access article published by Mehran University of Engineering and Technology, Jamshoro under CC BY 4.0 International License. 
includes crops, livestock, fisheries, agro-forestry and rangelands. Besides, agriculture is strongly linked with other sectors in terms of its inputs and outputs [11]. Many agro-based industries, such as textile, leather and food processing, have direct or indirect links to agriculture and its products. The change in household income based on change in agro-based income also affects the household consumer demand for the products from the other remaining sectors. Thus, climate change directly or indirectly impacts the overall economy through the agriculture sector.

The local climate and weather changes in Sindh may affect both crop yields and returns to farmers. By the virtue of its geographical location and climate, Sindh has been able to grow some crops, such as mangoes, tomatoes, onion, wheat and other crops, one month earlier than Punjab, and farmers in Sindh have benefitted from this as market prices are generally high in the beginning of crop season. However, climate change and weather variability may change this pattern resulting in uncertainty and riskier returns to farmers. Due to diverse geography of Sindh, climate and weather variability are likely to create a great deal of uncertainty about agriculture sector and other economic sectors that depend on agriculture, which will have impacts on income, livelihood and poverty. Thus, there is a need to identify policy measures that would facilitate climate change adaptation measures in Sindh to mitigate the negative impacts of climate change on the agriculture sector and to avail opportunities from any positive impacts arising from climate change [12].

This study examines the past trend in climate variables and provides projections of trend in the variables in Sindh province of Pakistan. This study also reviews the climate change implications for agriculture sector and proposes adaptation strategies and options for policy makers and other relevant stakeholders.

\section{Data and Methods}

The study examines past trend in climate variables using data from 1961 to 2019 . The data on temperature and precipitation for different weather stations has been obtained from Pakistan Meteorological Department. The past trend in minimum temperature, maximum temperature and precipitation has been analyzed using linear regression model. Projections of future climate changes are presented based on the projected maps provided by the Intergovernmental Panel on Climate Change (IPCC). Since climate change impacts vary across time and space, the study highlights the impacts of change in climatic conditions on agriculture sector by reviewing cases documented in literature for Sindh. For identifying potential adaptation measures, the study reviews the literature from Sindh and other provinces, and also reviews international best practices, with focus on various adaptive pathways adopted around the world.

\section{RESULTS AND DISCUSSION}

The results on past trends and future projections of climate variables, their impacts, and adaptation measures for Sindh are presented in this section.

\subsection{Past Trend in Climate Variables}

Table 1 presents the station-wise trend in minimum temperature, maximum temperature and precipitation for different meteorological stations in Sindh. For each station, we estimated linear regression model using monthly data from 1961-2019 to examine the trend in the weather variables. The table indicates 'upward' for a positive trend coefficient and 'downward' for a negative trend coefficient. The results show that at every location there has been an upward trend in either maximum or minimum temperature, or in both. Similarly, an upward trend has been observed in precipitation at most of the locations. Furthermore, Table 1 shows a mixed pattern of both upward and downward trends in temperature and precipitation but statistically significant trend has been observed in the temperature in some of the stations.

The previous study found an upward trend in area weighted annual maximum temperature anomaly time series over Sindh and also in other provinces of Pakistan using data from 1960 to 2007 [13]. The average annual temperature in Pakistan has increased in the past century (1900-2000) by $0.6{ }^{\circ} \mathrm{C}$, which is statistically significant at $99 \%$ confidence level $[14$, 15]. These studies have also found an upward trend in the precipitation in the past century, and more deviation in the temperature and precipitation. Furthermore, as cited in [3], the IPCC reports that sea level has risen roughly at the rate of 1.5 to $2.0 \mathrm{~mm} /$ year Mehran University Research Journal of Engineering and Technology, Vol. 39, No. 3, July 2020 [p-ISSN: 0254-7821, e-ISSN: 2413-7219] 
during $20^{\text {th }}$ century and continues to rise in $21^{\text {st }}$ century.

\subsection{Projections of Trend in Climate Variables}

Table 2 presents the projections of change in temperature and precipitation in Sindh based on authors' extractions from the projections provided in IPCC Assessment Report 5. The projections in Assessment Report 5 are based on RCP (Representative Concentration Pathways) scenarios. RCP is a latest addition to the IPCC scenarios that provides input to climate models. There are four such scenarios, based on the amount of emissions measured by each scenario, RCP 8.5, RCP 6, RCP 4.5 and RCP 2.6, which signify high, intermediate and low emissions respectively. RCP 6 and 4.5 both indicate intermediate emissions [16]. According to the availability of projections provided in the report, the findings of temperature and precipitation change are displayed under each RCP and respective time-period.

Table 2 shows that under RCP 4.5 which entails relatively ambitious fall in emissions, the temperature is expected to rise during December - February (0.75 to 1.5 degrees) and June - August (0.5 to 1 degrees) accompanied with some degree of variability, i.e. standard deviation, in the medium term. Therefore, in

near future we expect increase not only in the average temperature in Sindh but also the variation in temperature. Precipitation in Sindh is expected to increase by 0 to $20 \%$. Similarly, under the same scenario in long term, rise in temperature can go as high as 2 to 3 degrees. Under RCP 6.0, which implies the use of technology to reduce emissions, the annual temperature change in long term can be between 2 to 4 degrees. Finally, under RCP 8.5, which is the business as usual scenario, i.e. if no protective measures are taken against the climate change, then rise in the annual temperature can go as high as 4 to 5 degrees. The precipitation can follow a highly erratic pattern. The projections indicate that the monsoon spells may extend up to November, affecting the crop yields and production systems for many crops.

The previous study has provided month-wise projections of precipitation in upper, central and lower parts of Sindh, and found that there would be more seasonal variation in the amount of rainfall, and the pattern of variation would also be different in various parts of Sindh, with some areas receiving more rainfall in one decade and meagre in the next [13]. Their projections show that the months of monsoon season are likely to vary across decades and across different parts of Sindh.

\subsection{Climate Change Impacts}

We examine the climate change impacts based on the various existing studies.

\subsubsection{Overall Impacts}

Table 3 presents the projected climate change impacts in Pakistan according to a World Bank study based on

Table 1: Trend in temperature and precipitation at various meteorological stations of Sindh

\begin{tabular}{|c|c|c|c|}
\hline Station & $\begin{array}{c}\text { Trend in Maximum } \\
\text { Temperature }\end{array}$ & $\begin{array}{c}\text { Trend in Minimum } \\
\text { Temperature }\end{array}$ & Trend in Precipitation \\
\hline Jacobabad & Downward & Upward & Upward* \\
\hline Larkana & Downward*** & Upward & Downward \\
\hline Moen-Jo-Daro & Upward & Upward $^{* *}$ & Upward \\
\hline Hyderabad & Downward & Downward & Downward \\
\hline Nawabshah & Upward* & Upward & Upward \\
\hline Rohri & Upward & Upward & Upward \\
\hline Padidan & Upward & Upward* & Upward \\
\hline Khairpur & Downward & Upward & NA \\
\hline Badin & Downward & Upward** & Upward \\
\hline Chhor & Upward $^{* *}$ & Upward & Upward \\
\hline Karachi (Airport) & Upward $^{* * *}$ & Upward $^{* * *}$ & Downward \\
\hline Karachi (Masroor) & Upward $^{* *}$ & Upward & Downward* \\
\hline
\end{tabular}

Note: $* * *$ and $* * *$ denote significance at $10 \%, 5 \%$ and $1 \%$, respectively, NA denotes data not available. 
Table 2: Projections of Temperature and Precipitation for Sindh

\begin{tabular}{|c|c|c|c|c|}
\hline \multicolumn{5}{|c|}{ Intermediate Emissions (RCP 4.5) } \\
\hline \multicolumn{5}{|c|}{ Medium Term $(2016$ - 2035) } \\
\hline+2 & $\begin{array}{l}\text { Dec- } \\
\text { Feb }\end{array}$ & $\begin{array}{l}\text { March- } \\
\text { May }\end{array}$ & $\begin{array}{l}\text { June- } \\
\text { Aug }\end{array}$ & $\begin{array}{l}\text { Sep- } \\
\text { Nov }\end{array}$ \\
\hline $\begin{array}{l}\text { Temperature } \\
\text { Change }\left({ }^{0} \mathrm{C}\right)\end{array}$ & $\begin{array}{l}0.75 \\
\text { to } 1.5\end{array}$ & - & 0.5 to 1 & - \\
\hline $\begin{array}{l}\text { Standard } \\
\text { Deviation } \\
\left({ }^{0} \mathrm{C}\right)\end{array}$ & $\begin{array}{l}0.25 \\
\text { to } 0.5\end{array}$ & - & 0 to 0.5 & - \\
\hline $\begin{array}{l}\text { Precipitation } \\
\text { Change }(\%)\end{array}$ & $\begin{array}{c}0 \text { to } \\
10\end{array}$ & 0 to 10 & 0 to 10 & $\begin{array}{l}0 \text { to } \\
20\end{array}$ \\
\hline \multicolumn{5}{|c|}{ Long Term (By the end of $21^{\text {st }}$ Century) } \\
\hline $\begin{array}{l}\text { Annual } \\
\text { Temperature } \\
\text { Change }\left({ }^{0} \mathrm{C}\right)\end{array}$ & \multicolumn{4}{|c|}{2 to 3} \\
\hline \multicolumn{5}{|c|}{ Intermediate Emissions (RCP 6.0) } \\
\hline \multicolumn{5}{|c|}{$\begin{array}{l}\text { Long Term } \\
\text { (By the end of } 21^{\text {st }} \text { Century) }\end{array}$} \\
\hline $\begin{array}{l}\text { Annual } \\
\text { Temperature } \\
\text { Change }\left({ }^{0} \mathrm{C}\right)\end{array}$ & \multicolumn{4}{|c|}{2 to 4} \\
\hline \multicolumn{5}{|c|}{ High Emissions: Business as Usual (RCP 8.5) } \\
\hline \multicolumn{5}{|c|}{ Long Term (By the end of $21^{\text {st }}$ Century) } \\
\hline \multirow[t]{2}{*}{$\begin{array}{l}\text { Annual } \\
\text { Temperature } \\
\text { Change }\left({ }^{0} \mathrm{C}\right)\end{array}$} & \multicolumn{4}{|c|}{4 to 5} \\
\hline & $\begin{array}{l}\text { Dec- } \\
\text { Feb }\end{array}$ & $\begin{array}{l}\text { March- } \\
\text { May }\end{array}$ & $\begin{array}{l}\text { June- } \\
\text { Aug }\end{array}$ & $\begin{array}{l}\text { Sep- } \\
\text { Nov }\end{array}$ \\
\hline $\begin{array}{l}\text { Precipitation } \\
\text { Change }(\%)\end{array}$ & $\begin{array}{c}-10 \text { to } \\
10\end{array}$ & -20 to 0 & $\begin{array}{l}0 \text { to } \\
20\end{array}$ & $\begin{array}{l}20 \\
\text { to } \\
50 \\
\end{array}$ \\
\hline
\end{tabular}

Source: Authors' extractions from IPCC Assessment Report 5 [17-18].

the plausible future climate scenarios [15]. The table shows that Pakistan's GDP is estimated to be lower by 1.1 percent annually due to climate change. Furthermore, the agricultural value-added to GDP is estimated to be lower by 5.1 percent annually, and household income is estimated to be lower by 2 percent, attributed to climate change.

Table 3: Projected Climate Change Impacts in Pakistan

\begin{tabular}{|l|c|}
\hline & $\begin{array}{c}\text { Average annual } \\
\text { change }(\%)\end{array}$ \\
\hline GDP & -1.10 \\
\hline $\begin{array}{l}\text { Agricultural value-added } \\
\text { to GDP }\end{array}$ & -5.10 \\
\hline Household Income & -2.00 \\
\hline
\end{tabular}

Source: Yu et al. [15]

The study further projects that climate change impacts on crop production will be highest in Sindh as compared to Punjab and other provinces. Their study projects that crop production in Sindh is estimated to be lower by 10 percent annually, on average, due to climate change [15].

Table 4 provides a summary of overall impact of climate change on major crops, namely wheat, cotton, rice and sugarcane, based on the reviewed literature. The table also sheds light on how a particular climate variable can likely affect yields of these major crops in Pakistan and Sindh.

\subsubsection{Livestock}

Livestock is a source of income for small farmers, especially in rain fed areas including desert and mountainous areas of Sindh. Climate change may affect livestock in these areas through the spread of vector-borne diseases, macro parasites, and shortage of fodder due to droughts. For rural households and dwellers of Thar Desert this means a push into chronic poverty due to their substantial dependence on livestock raising [19]. Livestock productivity is also expected to be affected by climate change through the channel of high temperatures; the impacts may include physiological stress on animals, reduction in milk and meat production, stressed conception, increased water requirements and fodder crops [20].

Table 4: Impact on Crops

\begin{tabular}{|c|c|c|c|c|}
\hline \multirow{2}{*}{ Wheat } & Climate Variable & Impact on Yield & Place of Study & References \\
\hline \multirow{2}{*}{ Cotton } & Temp: $+1^{\circ} \mathrm{C}$ to $4^{\circ} \mathrm{C}$ & -9 to $30 \%$ & Pakistan & Mallick and Masood [21] \\
\cline { 2 - 3 } & Temp: $+1^{\circ} \mathrm{C}$ & $-2.26 \%$ & Sindh & Raza and Ahmad [22] \\
\cline { 2 - 3 } Rice & Percipitation: + & Decrease & & \\
\cline { 2 - 3 } & Mean Max Temp: & Decrease & Pakistan & Shakoor et al. [23] \\
\cline { 2 - 3 } Sugarcane & Temp: $+1^{\circ} \mathrm{C}$ & $+7 \%$ & Pakistan & Afghan and Jamil [24] \\
\hline
\end{tabular}




\subsubsection{Livestock}

Livestock is a source of income for small farmers, especially in rain fed areas including desert and mountainous areas of Sindh. Climate change may affect livestock in these areas through the spread of vector-borne diseases, macro parasites, and shortage of fodder due to droughts. For rural households and dwellers of Thar Desert this means a push into chronic poverty due to their substantial dependence on livestock raising [19]. Livestock productivity is also expected to be affected by climate change through the channel of high temperatures; the impacts may include physiological stress on animals, reduction in milk and meat production, stressed conception, increased water requirements and fodder crops [20].

\subsubsection{Fisheries}

According to a study by World Bank, the deltaic region of Indus is getting drier and saltier as it receives meagre amounts of fresh water and as consequence, the depletion of fish along the coast is a major issue in Sindh. Many fish species have become extinct and others are close to extinction [25]. Furthermore, the rise in temperature has resulted in shifting distribution of fish species, has affected their growth rates, and has decreased availability of oxygen [19].

\subsubsection{Sea Intrusion}

With growing water scarcity, fresh river water supply to downstream Kotri Barrage has declined [25]. An important consequence of water scarcity in Sindh and sea level rise is the intrusion of seawater into the Indus Delta. This has resulted in soil salinity along the delta, deterioration of mangrove cover and loss of marine fisheries [25]. Along with cyclones that hit coastal areas, sea intrusion has led to the invasion of seawater, occupying 54 kilometers into the Indus Delta along the river's course. The sea has conquered over 1.2 million acres of fertile agricultural land in Thatta district and nearby areas, adversely affected mangrove and riverine forests, also has resultantly led to a decline in wildlife, migratory birds, fish and shrimp species [21]. It is estimated that the sectors of agriculture, forestry and fisheries may bear a loss of Rs. 1.3 billion over the period 2000-2025 [26]. Another study estimated that $39 \%$ of the agricultural land has been badly affected by seawater intrusion and $11 \%$ of the cultivated land *has partially been affected and is at the risk of further degradation in Sindh [25]. The situation has hurt the dwelling livelihoods, as the region has experienced a drop in agricultural productivity and decline in fish catches, ultimately causing forced migration for survival.

Mangrove forests are a much-cherished resource of the province as they are a source of not only fuel wood but also food to local inhabitants [27]. At present only 15\% mangroves is healthy [28]. The rate of degradation of mangroves forests in the Indus delta has been estimated at 6\% during 1980 to 1995 . Also, the reduced rainfall at the coast and Indus Delta (10$15 \%$ lower in the last 40 years) continue to severely degrade the country's wetland and mangrove ecosystems [29]. Estimations show that annual losses due to mangrove loss stand at approximately $0.3 \%$ of provincial GDP of Sindh in 2010 [25].

According to IPCC fourth assessment report, sea levels during the 20th century rose about 15-20 centimeters (roughly 1.5 to $2.0 \mathrm{~mm} /$ year), with the rate at the end of the century increased to about 3.1 $\mathrm{mm} / \mathrm{year}$, which is significantly higher than the average rate for the 20th century. Sea level rise would be a prime factor of flooding in coastal areas, which is apparently an issue of today [3]. Sea level rise has increased vulnerability of low lying coastal areas. Salt water from sea level rise will negatively affect farther upstream ultimately increasing brackishness of water and threatening human use and aquatic life [30].

\subsubsection{Impact on Poverty and Livelihoods}

Due to the heavy reliance of poor on natural resources, capital degradation associated with climate change reduces their assets and keeps them trapped in the poverty's circle [31]. Small farmers tend to get more affected than big farmers. Due to their limited landholding size, their lands get washed away in flooding season or by any natural calamity, and the extent of impact is much stronger on small landholders than larger landholders. If any natural calamity strikes, small farmers lose a larger share of their income [32]. In Sindh, around $68 \%$ of rural population is engaged in agricultural activities, which is quite a huge 
dependency on agriculture [28]. In addition, any serious decreases in agricultural yield due to climate change adversely affect the income levels of those whose sole source of earning is agriculture. It can further push them below subsistence levels if no investments are made into combating climate change. A World Bank study [15] found that household income could decrease by about 2 percent in Pakistan owing to climate change.

The loss of biodiversity in delta area is a threat to the poor dwelling communities, and only makes them more vulnerable to climate change in form of sea intrusion and loss of breeding grounds of fish as highlighted in above sections. Prawns and crabs have vanished after the cyclone that hit coastal areas in 1999 and the drying up of wetlands has seriously affected the fishing communities in district Badin resulting in migration of workers to nearby urban areas [33].

\section{ADAPTATIONS OPTIONS}

\subsection{Impact of Adaptation Investments}

A recent study by the World Bank evaluated the impacts of adaptation investments in Pakistan [15]. The study evaluated three adaptation investments: investments in agricultural technologies to increase crop yield, investment for canal and watercourse efficiency improvements, and construction of new reservoirs to introduce an additional 13 MAF. Table 5 presents the main findings including the impacts on GDP, agricultural value-added to GDP, and household income. The findings of the study show that the climate change is likely to reduce agricultural valueadded to GDP by around 5\% if there is no investment made for climate change adaptation. However, the investment in agricultural technologies to increase crop yield is likely to increase the agricultural valueadded to GDP by around $17 \%$ while the investment for canal and watercourse efficiency improvements would increase it by $9 \%$.

Grost et al. [34] estimate the impacts of adaptations on productivity of different crops and find that adaptation was linked to increased yields. Positive effects for wheat and cotton outweighed rice. Some adaptations included: changing the sowing time depending upon when the farmers find optimal temperatures and other inputs, secondly changing the variety of crop i.e. substituting less vulnerable crops for those that are more vulnerable to climate change, thirdly farmers could opt for changing the input mix, and lastly by conserving soil quality and keeping soils enough irrigated. Factors that induced farmers to adapt to climate changes were also analyzed. For adapters cotton and wheat yield is estimated to increase by $9 \%$ and $12 \%$ respectively, and $3 \%$ for rice.

Farmers have delayed wheat sowing 2-3 weeks throughout the country to avoid higher temperature level above optimal, from mid-October to earlyNovember [35].

Ahmad et al. [36] listed some adapted practices in rain fed and irrigated areas, including: installation of tubewells to lessen drought impacts; diversion of stream water by means of private channels; delayed sowing of crops to avoid negative impacts of elevated temperatures in rain fed areas; tunnel farming is gaining momentum to ensure availability of offseason crops; wheat in standing cotton is sowed (an example of double cropping); rice is directly seeded to lower the input costs, cotton is sown earlier to avoid high temperatures; intercropping wheat in sugarcane and mustard in cotton and heat tolerant varieties of rice are adopted in irrigated areas.

Table 5: Impact of Adaptation Investments in Pakistan [15]

\begin{tabular}{|l|c|c|c|}
\hline & $\begin{array}{c}\text { Change in } \\
\text { GDP }(\%)\end{array}$ & $\begin{array}{c}\text { Change in Agricultural } \\
\text { value-added to GDP (\%) }\end{array}$ & $\begin{array}{c}\text { Change in Household } \\
\text { Income }(\%)\end{array}$ \\
\hline Average change without investments & -5.10 & -2.00 \\
\hline No investment & -1.10 & 16.70 & 5.42 \\
\hline Average change with investments & 3.66 & 9.32 & 3.21 \\
\hline $\begin{array}{l}\text { Investments in agricultural to increase crop } \\
\text { yield }\end{array}$ & 2.09 & 1.50 & 0.64 \\
\hline $\begin{array}{l}\text { Investments for canal and watercourse } \\
\text { efficiency improvements }\end{array}$ & 0.29 & & \\
\hline Construction of new reservoirs & & & \\
\hline
\end{tabular}

Mehran University Research Journal of Engineering and Technology, Vol. 39, No. 3, July 2020 [p-ISSN: 0254-7821, e-ISSN: 2413-7219] 


\section{CONCLUSION AND POLICY RECOMMENDATIONS}

As per the projections provided in the IPCC report 5, the average temperature and the variation in temperature in Sindh are expected to rise due to climate change. Precipitation in Sindh is also expected to increase and expected to follow a highly erratic pattern. The projections further indicate that the monsoon spells may extend up to November, affecting the crop yields and production systems for many crops. This will have serious implications for agriculture sector and other sectors directly or indirectly linked to agriculture. The sub-sectors of agriculture - crops, livestock and fishing - will have negative effect and consequently lowered trajectory of household income, aggravating already high rural poverty rate in the province.

The adverse impacts of climate change could be addressed by policy response and its implementation at field level. Strong and timely public policy with adequate investment in adaptation could greatly help in minimizing the negative climate change impacts.

A resilient and climate change adapted agriculture will require: (a) suitable agriculture practices, to address new opportunities and threats, resulting from higher temperature and rainfall; (b) suitable infrastructure, particularly at farm level, to deal with higher, but more variable rainfall, and floods and droughts along with well-planned response mechanisms; and (c) strong contingency plans and funds in case of unforeseen disasters.

The specific recommendations for climate change adaptations are as follows:

Modify farming systems to adapt to emerging climate patterns: This would include better extension and farmer trainings services, provision of quality seed, and redefining cropping zones. Providing updated information to farmers is very important for management of farms. Agricultural extensions can play a role in spreading adaptation knowledge. To strengthen the current agriculture extension system, rigorous training and information sessions of the officers should be conducted to build their capacities that can outweigh the prevailing challenges. Seed quality should correspond to the type of soil and climatic conditions. As the temperature is increasing and other climate variables are also changing, seeds should be well adapted to give good yields. This can also be a great opportunity of research in climate smart agriculture. In this regard, Sindh Seed Corporation should play its part and a division of this entity should solely be engaged in research and development of new seed varieties and animal breeds with increased resistance to heat shocks, droughts, flooding and salinization.

Increase public development and research funding for climate smart-agriculture: The Government should improve productive and protective infrastructure in rural areas, both public and private infrastructure, to deal with bigger and more frequent floods and seawater intrusion. The Government should also provide resources for disaster relief and rehabilitation, with a particular focus on vulnerable areas and on the poor. Also, maintenance of existing irrigation infrastructure including proper drainage in LBOD and RBOD should be ensured.

Promoting Adaptation by Farmers: The Government needs to promote various adaptation measures by farmers. Altering cropping patterns and sowing time keeping in view climate projections needs to be supported. The income diversification for farmers may also be promoted. Mulching practice been observed in some parts of Sindh in which the top soil is covered with a layer of organic or inorganic materials. It helps preventing soil from eroding, maintains moisture, and enhances soil filtration. Such practices should be encouraged on large scale.

Providing timely weather forecasts through Short Message Service (SMS) and other channels to farmers: Pakistan Meteorological Department should furnish timely weather updates and forecasts for farmers in order to facilitate them in deciding appropriate timing in all activities from sowing to harvesting. It can be done by making responsible few people across all meteorological stations to send related data to farmers through SMS system. For this purpose, the farmers can be asked to register themselves at these stations to receive messages. In addition, it should be made free of cost for farmers to receive such messages. It can serve as an early warning system for them that may be beneficial in terms of avoiding losses, which might 
have occurred if that information was not available to them.

\section{REFERENCES}

[1] UNDP, "Pakistan: Climate Public Expenditure and Institutional Review (CPEIR)". United Nations Development Programme, Pakistan, Islamabad. 2015.

[2] Eckstein, D., Kunzel, V., Schfer, L. and Winges M, "Global Climate Risk Index 2020: Who Suffers Most From Extreme Weather Events? Weather-related Loss Events in 2018 and 1999 to 2018", Germanwatch e.V., Bonn, Germany. 2019.

[3] Rasul, G., Mahmood A., Sadiq A. and Khan S. I, "Vulnerability of the Indus Delta to Climate Change in Pakistan". Pakistan Journal of Meteorology, Vol. 8, No. 16, pp. 89-107, 2012.

[4] Deschenes, O., and Greenstone, M, "The Economic Impacts of Climate Change: Evidence from Agricultural Output and Random Fluctuations in Weather". American Economic Review, Vol. 97, No. 1, pp. 354-385. 2007.

[5] Ahmed M. N and Schmitz M, "Economic Assessment of the Impact of Climate Change on the Agriculture of Pakistan". BEH Business and Economic Horizons. 4(1). 1-12. 2011.

[6] Cline, W. R, "Global Warming and Agriculture: Impact Estimates by Country". Peterson Institute. 2007.

[7] Dinar, A., and Mendelsohn, R. O. (Eds.), "Handbook on Climate Change and Agriculture". Edward Elgar Publishing. 2011.

[8] Janjua, P. Z., Samad, G., Khan, N. U., and Nasir, M, "Impact of Climate Change on Wheat Production: A Case Study of Pakistan" The Pakistan Development Review, Vol. 49, No. 4, pp. 799-822. 2010.

[9] Kumar, K. K, "Climate Sensitivity of Indian Agriculture: Do Spatial Effects Matter?" Cambridge Journal of Regions, Economy and Society, Vol. 4, No. 2, pp. 221-235. 2011.

[10] Government of Pakistan, "Pakistan Economic Survey 2019-20". Finance Division, Government of Pakistan. 2020.
[11] Government of Pakistan, "Pakistan Economic Survey 2013-14". Finance Division, Government of Pakistan. 2014.

[12] Government of Sindh, "Sindh Agriculture Policy (2018-2030)". Government of Sindh, Karachi. 2018

[13] Rasul G., Chaudhry, Q. Z., Mahmood A and Hyder K. W, "Effect of Temperature Rise on Crop Growth \& Productivity". Pakistan Journal of Meteorology, Vol. 8, No. 15, pp. 53-62, 2011.

[14] Sheikh, M. M., Manzoor, N., Adnan, M., Ashraf, J., and Khan, A. M, "Climate Profile and Past Climate Changes in Pakistan, GCISCRR-01", Global Change Impact Studies Centre (GCISC), Islamabad, Pakistan, ISBN: 978-9699395-04-8, 2009.

[15] Yu, Winston, Yi-Chen Yang, Andre Savitsky, Donald Alford, Casey Brown, James Wescoat, Dario Debowicz, and Sherman Robinson, "The Indus Basin of Pakistan: The Impacts of Climate Risks on Water and Agriculture. Washington, DC": World Bank. doi: 10.1596/978-0-8213-9874-6. License: Creative Commons Attribution CC BY 3.0. 2013.

[16] Bjørnæs, C. "A guide to Representative Concentration Pathways. CICERO". Center for International Climate and Environmental Research. 2013.

[17] Kirtman, B., S.B. Power, J.A. Adedoyin, G.J. Boer, R. Bojariu, I. Camilloni, F.J. DoblasReyes, A.M. Fiore, M. Kimoto, G.A. Meehl, M. Prather, A. Sarr, C. Schär, R. Sutton, G.J. van Oldenborgh, G. Vecchi and H.J. Wang, "Nearterm Climate Change: Projections and Predictability. In: Climate Change 2013: The Physical Science Basis. Contribution of Working Group I to the Fifth Assessment Report of the Intergovernmental Panel on Climate Change [Stocker, T.F., D. Qin, G.-K. Plattner, M. Tignor, S.K. Allen, J. Boschung, A. Nauels, Y. Xia, V. Bex and P.M. Midgley (eds.)]". Cambridge University Press, Cambridge, United Kingdom and New York, NY, USA.

[18] Collins, M., R. Knutti, J. Arblaster, J.-L. Dufresne, T. Fichefet, P. Friedlingstein, X. Gao, W.J. Gutowski, T. Johns, G. Krinner, M. 
Shongwe, C. Tebaldi, A.J. Weaver and M. Wehner, "Long-term Climate Change: Projections, Commitments and Irreversibility. In: Climate Change" The Physical Science Basis. Contribution of Working Group I to the Fifth Assessment Report of the Intergovernmental Panel on Climate Change [Stocker, T.F., D. Qin, G.-K. Plattner, M. Tignor, S.K. Allen, J. Boschung, A. Nauels, Y. Xia, V. Bex and P.M. Midgley (eds.)]. Cambridge University Press, Cambridge, United Kingdom and New York, NY, USA.

[19] WWF, Pakistan, "Disaster Management Plan for Livestock and Fisheries Sectors of Sindh. 2014.

[20] Hussain, S, “Adaptation needs for Agriculture and Water Resources in KP”, Pakistan. 2013.

[21] Mallick, S., Masood, M, "Environment, Energy and Climate Change in Pakistan: Challenges, Implications and Required Responses". Mahbub ul Haq Human Development Centre Working Paper Series. 2011.

[22] Raza, A., and Ahmad M, "Analysing the Impact of Climate Change on Cotton Productivity in Punjab and Sindh, Pakistan”. Climate Change Working Papers No. 9. Pakistan Institute of Development Economics Islamabad. 2015

[23] Shakoor, U., Saboor, A., Baig, I., Afzal, A., and Rahman, A., "Climate Variability Impacts on Rice Crop Production in Pakistan", Pakistan Journal of Agriculture Research, Vol. 28, No. 1,2015

[24] Afghan, S. and Jamil, M, "Climate Change Impact on Sugar Industry of Pakistan- An Overview" Conference Paper. https://www.researchgate.net/publication/2674 53686. 2013

[25] Sánchez-Triana, Ernesto, Santiago Enriquez, Bjorn Larsen, Peter Webster, and Javaid Afzal, with contributions from Elena Strukova Golub, Hammad Raza, Mosuf Ali, and P. S. Rajani, "Sustainability and Poverty Alleviation: Confronting Environmental Threats in Sindh, Pakistan" Directions in Development. Washington, DC: World Bank, doi:10.1596/978-1-4648-0452-6, 2015.
[26] IUCN (International Union for Conservation of Nature), "Environmental Degradation and Impacts on Livelihoods: Sea Intrusion, A Case Study”, IUCN Pakistan, Sindh Program Office. 2003.

[27] Farooqi, B, A., Khan, H, A, and Mir, H, "Climate Change Perspective in Pakistan" Pakistan Journal of Meteorology, Vol. 2, No. 3, pp. 11-21. 2005.

[28] Tagar, H. K., and Shah, A. R. A, "Sindh Agro Eco System: Major Obstacles and Remedies" International Journal of Innovative Research and Development, Vol. 4, No. 5, 2013.

[29] GFDR, "Building Resilience to Disasters Delivering Results". Annual Report 2011. Global Facility for Disaster Reduction and Recovery. Washington, DC 20433, USA. 2011.

[30] Rabbani, M. M., Inam, A., Tabrez, A. R., Sayed, N. A, and Tabrez, S. M, "The Impact of Sea Level Rise on Pakistan's Coastal Zones in a Climate Change Scenario". National Institute of Oceanography.

[31] UNFPA (United Nations Population Fund), "State of World Population 2009: Pakistan Supplement - Holding Up the Sky": Women, Population and Climate Change. Pakistan: UNFPA, 2009.

[32] Hallegatte, S., Bangalore, M., Bonzanigo, L., Fay, M., Kane, T., Narloch, U., ... and VogtSchilb, A, "Poverty and Climate Change: Natural Disasters, Agricultural Impacts and Health Shocks". Towards a Workable and Effective Climate Regime, pp. 369, 2015.

[33] Rao, Z., and Maqbool, I, "Climate Change Risks and Vulnerabilities of Badin District in Sindh Province", Pakistan. Asian Disaster Preparedness Center, Bangkok, Thailand, 2014

[34] Gorst, A., Groom and B., \& Dehlavi, A, "Crop Productivity and Adaptation to Climate Change in Pakistan". Grantham Research Institute on Climate Change and the Environment Working paper, (189). 2015. 
[35] Ahmad, M,. Siftain, H and Iqbal, M, "Impact of Climate Change On Wheat Productivity In Pakistan: A District Level Analysis". Climate Change Working Paper Series No. 1, Pakistan Institute of Development Economics Islamabad, 2014.

[36] Ahmad, M., Iqbal, M., and Khan, M. A, "Climate Change, Agriculture and Food Security in Pakistan: Adaptation Options and Strategies". Pakistan Institute of Development Economics, Islamabad. (Climate Change Brief), 2013. 